\title{
STOCK OPTION PLANS FOR EXECUTIVES
}

Fair executive compensation is a very real problem today. ${ }^{1}$ Taxes and the high cost of living have greatly reduced the take-home pay of all persons deriving income from personal services. ${ }^{2}$ The entrepreneur, however, in a business where he can build up his equity and subsequently dispose of it at capital gain rates has a formidable advantage over the salaried employee. Just how the employee will be compensated is usually achieved through a balance of substantive law, ${ }^{3}$ taxation, and employee interests, adjusted to fit the peculiarities of the individual company. The employee stock option plan ${ }^{4}$ is a prevalent method of compensation which enables the salaried employee to secure some of the tax benefits of the entrepreneur. An added virtue of stock option plans is the incentive they may provide by encouraging an employee to secure a proprietory interest in the corporation. The disadvantage of the stock option is that little or no gain is immediately realized by the employee, the whole plan depending on a rising stock market. For executives who are not satisfied merely to speculate on a rising market, other methods of compensation must be available. ${ }^{5}$

\section{TAX PROBLEMS}

The manner in which income tax laws deal with stock option plans greatly affects the extent of their use. Prior to 1946, the Internal Revenue Code and case law distinguished between stock options given as a proprietory interest and options given as compensation, ${ }^{6}$ In the former case no income resulted at the time of the grant or exercise of the option, and no deduction was available to the employer. In the latter situation any difference between the option price and the market price at time of exercise would be considered salary. Stock option plans during this period were fairly common, since it was not difficult to fall under the favored classification. However, in 1945, the Supreme Court ruled that any differential of the market price over the option price on exercise was taxable as regular income. $^{7}$ In 1946 , the treasury regulations were accordingly changed. ${ }^{8}$ The 1951).

1 See Washongton and Rothschim, Compensating the Corporate Executive (2d ed.

2 See Dean, Employee Stock Options, 66 HARv. L. Rev. 1403 (1953).

3 Wage stabilization controls repealed. EXEC. ORDER No. 10434, 18 FED. REg. 809 (1953).

4 See Surrey and Warren, Federal Income Taxation 588-609 (3d ed. 1953); WastINGTON AND RothSCHTLD, op. cit. supra note 1 at 121-167; Comment, 51 Mich. L. Rev. 559 (1953); Notes, 62 YaLe L. J. 84 (1952); 53 CoL. L. Rev. 283 (1953); 52 CoL. L. Rev. 1003 (1952).

5 Other forms of compensation are: profit sharing agreements; stock purchase plans; deferred compensation plans; direct salary agreements, etc. See WASEmGTON AND ROTHSCHUD, op. cit. supra note 1.

G Geeseman v. Commissioner, 38 B.T.A. 258 (1938); U.S. TREAS. REG. 111 (1943); SURREY AND WARREN, op. cit. supra note 4 at 588-592, 609; WASEDNGTON AND ROTHSCEED, op. cit. supra note 1 at 129-134; Lyon, Employee Stock Options Under the Revenue Act of 1950, 51 Cor. L. Rev. 1 (1951).

7 Commissioner v. Smith, 324 U.S. 177 (1945).

8 T.D. 5507, 1 Cum. BuLL. 18 (1946); I.T. 3795, 1 Cusr. BuLr. 15 (1946). 
result was the virtual abandonment of the stock option plan. ${ }^{\circ} \mathrm{A}$ wave of protests followed. ${ }^{10}$ So severe was this deluge of disapproval, that in 1950 Section $130 \mathrm{~A}$ of the Internal Revenue Code was passed by Congress. ${ }^{11}$

Upon complying with the conditions of Section 130A, no tax is levied until profits are actually realized by a sale of the stock acquired pursuant to the option and capital gain benefits may be easily achieved. ${ }^{12}$ Since September of 1950 stock option plans have flourished. ${ }^{13}$ Although larger companies find it easier to apply Section 130A, since the market value of their stock is readily known, small companies as well are turning to the Section 130A stock option. ${ }^{14}$

It should be noted that stock option plans that do not qualify under Section $130 \mathrm{~A}$ are still controlled tax-wise by prior law. Although it is as yet untested, the 1946 regulation, as well as Commissioner $v . S m i t h{ }^{15}$ are formidable obstacles in the path of deferred taxation. ${ }^{10}$ However, it seems some courts may nevertheless attempt to give the optionee a tax advantage. ${ }^{17}$ Capital gain benefits have been allowed on the actual sale of stock when the court found the optionee had only a limited ownership, that is, restrictions of transfer in the stock acquired pursuant to the option. ${ }^{18} \mathrm{~A}$

9 Fetter and Johnson, Compensation and INCENTIVe for INDUSTrial Executives 95 (1952) (2 of 50 companies studied had stock options between 1945 and 1949). From 1928 to 1938 about 25 to 35 per cent of listed corporations adopted stock option plans. Baker, Stock Options for Executives, 19 HARV. L. REv. 107, 121 (1940).

${ }^{10}$ See SURREX AND WARREN, op. cit. supra note 4 at 598-606.

11 REVENUE ACT OF 1950, 26 U.S.C. §130A (1952 pocket supp.).

12 INT. REV. CODE $\$ 130 A$ sets up the following basic requirements:

A. The option price of the stock must be at least $85 \%$ of the fair inarket value at the time the option is granted (95\% to secure capital gaim). INT. REv. CoDE $\$ 130 A(d)(1)(A)$. See Dean, supra note 2 at 1412, for discussion of determining "fair inarket value."

B. The option must be granted by a corporation to an employee for employment purposes. INT. REv. CODE $§ 130 A$ (d) (1). See Dean, supriz note 2 at 1416.

C. The option must be non-transferable except upon death. INT. Rev. CODE $\S 130 \mathrm{~A}$ (d) (1) (B). See Dean, supra note 2 at 1409 , on efiect of the optionec's death.

D. The option must be exercised during employment or not later than three months after termination of services. INT. REv. CODE $\$ 130 A$ (a). See Dean, supra note 2 at 1409.

E. The stock subject to the option must be held for two years after its grant and six months after the exercise of the option. INT. REv. CODE $\$ 130 A$ (a). See Dean, supra note 2 at 1414, for discussion on: "When is an option granted?"

F. The optionee must hold less than 10 per cent of voting stock of corporation. INT. REv. CODE $\$ 130(A)$ (d) (1) (C). For discussion: see citations, SURREY AND WARREN, op. cit. supra note 4 at 609; WASHINGTON AND RotHSCHID, op. cit. supra note 1 at 136-148.

13 Plans that qualify under $\$ 130 \mathrm{~A}$ are labeled "Restricted Stock Option." INT. REV. CODE $\S 130 \mathrm{~A}(\mathrm{~d})(1)$.

14 Wall Street Journal, Pac. Coast Ed., Aug. 6, 1952, p. 1, col. 5 (300 major American corporations reported use of stock option plan in period between Sept. 1950-Aug. 1952); cf. MCKensey AND Co., Stock Option AS AN INCENTIVE For Executives (1952) (1 out of 6 companies on New York Stock Exchange have stock option plans).

15 Supra note 7.

${ }^{16}$ Sustaining the Simith case, Van Dusen v. Commissioner, 166 F.2d 647 (9th Cir. 1948); McNamara v. Commissioner, 19 T.C. No. 112 (CCH Dec. 19, 495) (1953).

17 Straus v. Commissioner, 11 T.C.M. 786 (CCH Dec. 19, 127M) (1952); Clark v. Commissioner, 9 T.C.M. 719 (CCH Dec. 17, 828M, (1950)). SURREY AND WARREN, citations and discussion, op. cit. supra note 4 at $608,609$.

18 Compare Kuchman v. Commissioner, 18 T.C. No. 22 (1952) with Lehman v. Commissioner, 17 T.C. 652 (1951). In both cases the restrictions on the stock were of short duration 
like result has followed when the court has been convinced that the parties were dealing with the actual option or share warrants and not the shares that could be acquired thereunder ${ }^{19}$ Also pre-1946 tests are often used and the Smith case is ignored or distinguished. ${ }^{20}$ Clearly, there are possibilities of securing tax advantages to the optionee even though Section 130A does not apply. ${ }^{21}$

Section 130A is very explicit in its requirements for a qualified tax plan, but this very explicitness has, it seems, been a trap. Corporations and attorneys, quick to set up a plan that qualified under the section, neglected to comply with the necessary state corporation law. As a result, several recent cases indicate that plans which qualify under $130 \mathrm{~A}$ may nevertheless be invalid under corporation law. ${ }^{22}$

\section{CORPORATE PROBLEMS}

\section{In general}

In analyzing stock option plans, courts have emphasized that the validity of each plan can be ascertained only after a full consideration of the plan itself and of all surrounding facts and circumstances as well. This comment will attempt to classify and inspect the ingredients courts have established as affecting the validity of a plan. Naturally, corporation law differs between jurisdictions and local law controls, ${ }^{23}$ but the decisions and reasoning of recent cases of the courts of leading commercial states are strongly indicative of the trend in this area.

In large measure the problems arising under stock option plans do not differ from those arising with respect to other forms of compensation. The

(one year in the Kuchman case). An agreement not to sell during this period and to offer the stock back at the same price if the optionee left the company's employ within this time is essentially the restriction in the agreements. Such restrictions make it impossible to value the stock obtained when the option is exercised, hence the Smith case cannot control.

10 Estate of Stone v. Commissioner, 19 T.C. No. 105 (CCH Dec. 19,474) (1953). The distinction seems very tenuous.

20 Straus v. Commissioner, supra note 17; Clark v. Commissioner, supra note 17; cf. McNamara v. Commissioner, supra note 16.

21 See Dean, supra note 2 at 1414-1418.

22 Kerbs v. California Eastern Airway, Inc., 90 A.2d 652 (1952), rehearing denied, 91 A.2d 62 (Del. Sup. Ct. 1952), reversing 83 A.2d 473 (Del. Ch. 1951); Gottheb v. Heyden Chemical Corp., 90 A.2d 660, partial rehearing decided, 92 A.2d 594 (Del. Sup. Ct. 1952), aff'd prior holding, reversing 83 A.2d 595 (Del. Ch. 1951).

23 Several states have statutes concerning stock option plans:

(a) Cal. CoRP. CODE $\S \S 1107-1108$ (1948); PA. STAT. ANN. tit. 15, §§ 2852-612 (1938). If pre-emptive rights do not exist and authorized but unissued stock is available, the directors can, without shareholder vote, adopt an option plan. It should be noted that both the above provisions use the phrase "Stock Purchase Plan." It is not clear whether this covers stock option plans but seems probable that it does. See Eliasberg v. Standard Oil Co., 23 N.J. Super. 431, 440, 92 A.2d 862, 866 (1952). The above sections are subject to by-law or charter amendments restricting the directors' power.

(b) Irl. Rev. Stat. c. 32, \$157.24 (1935); Md. AnN. Code Gen. Laws art. 23, § 26(b) (1951); MIch. CoMP. LAW. \$ 450.24 (1948) ; N. J. Rev. Stat. \$§ 14; 9-1-3 (Supp. 1950); N. Y. Stock Corp. LAw § 14; OHIo GeN. Code ANN. § 8623-36 (1938). Plan must be approved by a specified vote of shareholders or a by-law provision.

(c) Some states have dissenters appraisal rights. See N.J. and N.Y. statutes, supra (b). 
courts have been reluctant to interfere with the judgment of corporate directors as to the reasonableness of compensation. ${ }^{24}$ If the compensation is fixed by a disinterested majority of the board of directors, or a majority of the shareholders ratify the action of an interested directorate, it is generally held that the burden of proof is upon the attacking shareholder to show the compensation to be so excessive as to amount to a gift in whole or in part. $^{25}$ This burden is satisfied only when the complainant can show that the compensation is clearly unreasonable, or that no adequate return of consideration is forthcoming from the recipient. ${ }^{26}$ If the court finds the compensation to be so clearly excessive as to amount to legal waste, to that extent the compensation will be held illegal. ${ }^{27}$ If on the other hand reasonably prudent directors might differ as to whether the compensation is excessive, the court will not substitute its judgment for the business judgment of corporate management. ${ }^{28}$ But if an interested board of directors acts to benefit itself and ratification is not obtained, under the majority rule the acts of the board are voidable on the part of the corporation regardless of fairness. ${ }^{29}$ A modern minority, however, places the burden of proof upon the interested board to prove good faith and fairness on their part, and if sustained their acts are valid. ${ }^{30}$ The business judgment rule does not here apply, and it has been repeatedly emphasized that here courts will closely scrutinize the board's actions. ${ }^{81}$

\section{Adequacy of consideration}

In the usual situation where a stock option plan is being attacked, the shareholder bears the burden of proving a waste of corporate assets. ${ }^{82}$ In this situation it is difficult to anticipate when the court will void a plan. Too great a disparity between option price and market price at either the time of issuance or exercise of a stock option increases the likelihood of a

24 Batlantine, Corporations 187-193 (2d ed. 1946).

25 Gottlieb v. Heyden Chemical Corp., supra note 22 ; Kaufman v. Shoenberg, 91 A.2d 786 (Del. Ch. 1952); Eliasberg v. Standard Oil Co., supra note 23; Batrantine, op. cit: stepra note 24, at $\$ \S 67-72$; Fletcher, Cyclopedia on Corporations $\$ \S 913,916,921$ (Perm. ed.).

26 Compensation plans of like companies rewarding like employees must be compared. Even with this evidence showing a clear disparity it is extremely difficult to prove that an employee's actual worth to a corporation is not what the directors say it is.

27 Rogers v. Hill, 289 U.S. 582 (1933). This result should not be altered by the fact that a statute exists authorizing payment for stock by labor and declaring the corporation directors' judgment as to the value of such labor conclusive. Such statute declared mapphicable. Gottlieb v. Heyden Chemical Corp., 92 A.2d 594 (Del. Sup. Ct. 1952).

28 Clamitz v. Thatcher Mfg. Co., 158 F.2d 687 (2d Cir. 1947), cert. denied, 331 U.S. 825 (1947); McQuillen v. National Cash Register Co., 27 F.Supp. 639 (D.C.Md. 1939), aff'd., 112 F.2d 877 (4th Cir. 1940); Kaufman v. Shoenberg, supra note 25; BALLANTINE, op. cit. stlpra note 24, $\$ \$ 42-43,62-63 a$; WASHINGTON AND ROTHSCAIDD, op. cit. supra note 1 at 383-412, and cases cited, 53 CoL. L. REv. 284, n. 11 (1953).

29 BaLIANTINE, op. cit. supra note $24, \S \S 67-72$ (general discussion).

30 Ibid.

81 See Gottheb v. Heyden Chemical Corp., supra note 22 at 663 . The plans themselves must withstand a rigid inspection to determine if the busmess judgment rule is applicable. Id. at 664 .

32 Since the directors are usually beneficiaries under any compensation plan, ratification is almost always obtained. 
court finding inadequate consideration..$^{33}$ However, a mere rise in the market price so that a large disparity exists when the option is exercised will not infect a plan. ${ }^{34}$ An advance in value is actually the hope of the parties. If the option is valid when given it is difficult for the court to say it must be exercised in a certain time or that it becomes unreasonable as the market price rises. Nevertheless, a reasonable time limit should be set beyond which an option cannot be granted or exercised to avoid possibilities of trouble. ${ }^{35}$

It seems that some courts will more easily find the necessary consideration if the stock option plan is expressly set up to increase incentive. The Supreme Court of Delaware asserted that the added effort and job satisfaction an option plan may promote is not enough "legal consideration" to validate the plan. ${ }^{36}$ However, the Chancery Court in a subsequent case, while acknowledging the above, nevertheless felt that the added effort and job satisfaction of optionees, with consequent additional benefits to the corporation was the "real" consideration sought by the corporation, although the court intimated that the options were neither necessary nor intended to retain the services of the optionees. ${ }^{37}$ The inference from both of these decisions is that little other consideration is necessary to validate a plan when the latter is expressly set up to increase the incentive of employees. On the other hand, an incentive option was recently upheld in New Jersey although the court stated there was no danger of losing the services of the beneficiaries under the plan, and that they were already. rendering their best efforts and full services. ${ }^{38}$ The court here stated bluntly that it is not illegal to grant an option plan for the purpose of giving optionees additional compensation subject to favorable tax rates. ${ }^{39}$ One authority at least, although written on the basis of fairly old cases, argues that courts should not put aside the question of reasonableness of consideration altogether and looks at the good faith of directors, the fairness of the plan and the compliance with all formal legal requirements. ${ }^{40}$ Today, however, although these factors are looked at also, courts to some degree always evaluate the reasonableness of the exchange of consideration.

33 Rosenthal v. Burry Bircuit Corp., 30 Del. Ch. 299, 60 A.2d 106 (1948). A Delaware District Federal Court has phrased the following test: If the option price is "so inequitable, oppressive, or unjust as to shock the conscience of the court or be fraudulent as without consideration" the plan will he invalidated. Wyles v. Campbell, 77 F. Supp. 343 (D. Del. 1948). Quote from Kingston v. Home Life Insurance Co. of America, 11 Del. Ch. 258, 101 Atl. 898 (1917), aff'd., 11 Del. Ch. 428, 104 Atl. 25 (1918); cf. Harker v. Ralston-Purina Co., 45 F.2d 929 (7th Cir. 1931), cert. denied, 284 U.S. 619 (1931).

34 Wyles v. Campbell, supra note 33 at 350; see Clamitz v. Thatcher Mfg. Co., supra note 28 (market price of stock almost doubled between option date and exercise of option); Abrams v. Allen, 36 N.Y.S.2d 174 (1942), aff'd., 266 App. Div. 835, 42 N.Y.S.2d 641 (1943) (market price almost tripled between option date and exercise of option). But cf. Rogers v. Hill, supra note 27.

35 See Dean, supra note 2 at 1426.

86 See Gottlieb v. Heyden Chemical Corp., supra note 22 at 664 ; Rosenthal v. Burry Biscuit Corp., 30 Del. Ch. 299, 60 A.2d 106 (1948).

8T See Kaufman v. Shoenberg, supra note 25 at 793.

38 See Eliasberg v. Standard Oil Co., supra note 23 at 869.

38 Id. at 870 .

40 Washington, Corporate Executrues' Comprensation 295 (1942). 
Another characteristic of a stock option plan that has been the basis of attack is its tax disadvantages to the corporation. Under compensation plans where the benefits to the employee are taxed immediately as ordinary income, the corporation can deduct these expenses from its gross income. ${ }^{41}$ Section 130A expressly allows no deduction to the corporation for the shares transferred under a restricted option plan. ${ }^{42} \mathrm{~A}$ like result would hold for plans that do not fall under Section 130A if the employee gain is not immediately taxed as income..$^{43}$ Recent decisions have emphasized that the tax loss to the corporation, in securing a tax advantage to the employee, is merely another factor that must be taken into account by the directors when setting up the compensation program. ${ }^{44}$ This tax disadvantage alone will not invalidate a stock option plan.

A gift of corporate assets will be found if the stock option plan is deficient because it is not "reasonably calculated" to "insure" that the company will receive the contemplated benefits to be bestowed by the optionee. ${ }^{45}$ Generally, a contract to pay an employee for services already performed is void for lack of consideration. An express or implied contract for compensation must have been agreed to prior to the performance of the services. ${ }^{40}$ The Delaware Supreme Court recently emphatically reaffirmed that stock options are governed by these rules. No plan can be created to compensate for past services, unless there was a prior agreement to set up a stock option after the services were bestowed. ${ }^{47}$ Normally no such agreement will be expressly or impliedly present, and therefore a stock option plan must be designed in exchange for the future services of the employee. The plan must "insure" that the future services of the optionee will be received by the corporation. In layman terms, the optionee must be "tied" in some way to the corporation. The Delaware Supreme Court appropriately made the following statement while attempting to formulate a rule to aid in the determination of whether the proper "insurance" is present: ${ }^{48}$

In view of the different circumstances of each corporation and of the permissible variations in the objects sought to be accomplished by stock option plans, the validity of each plan, of necessity, can be ascertained only after a full consideration, not only of the terms of the plan itself, but of all of the surrounding facts and circumstances as well. No rule of thumb can be devised to test the sufficiency of the conditions which are urged as insurance that the corporation will receive the contemplated benefit (emphasis added).

41 See INT. REv. Code $\$ 23(\mathrm{a})$.

42 See INT. Rev. CoDE $\$ 130 A(a)(2)$.

43 See INT. Rev. CODE $\$ 24$; SURRey AND WARREN, op. cit. supra note 4 at 592.

44 Kaufman v. Shoenberg, supra note 25.

45 Kerbs v. California Eastern Airways Inc., supra note 22; Kaufman v. Shoenberg, supra note 25; Eliasberg v. Standard Oil Co., supra note 23.

46 Corbin, Contracts $\$ \S 234,235$ (1952); Ballantmane, op. cit. sutpra note 24 at 187-192. See Holmes v. Republic Steel Corp., 84 Ohio App. 442, 84 N.E.2d 508 (1948); Note, 25 InD. L. J. 212 (1950).

47 Kerbs v. California Eastern Airways, Inc., supra note 22.

48 Id. at 656-657. 
The easiest and safest method of legally "tying" an optionee to the corportion is by an employment contract. ${ }^{99}$ The courts have recognized that personal service contracts normally cannot be specifically enforced. But nevertheless they consider as adequate evidence that an employee will give his future services to the corporation. ${ }^{50}$

Where no employment contract exists, the optionee must be "bound" to the corporation by some other means. Mere hope that the optionee will remain in the employ of the corporation will not suffice. ${ }^{51}$ Nor is it enough that to secure the benefits of Section 130A the optionee must be in the employ of the corporation when exercising the option. The court cannot "depend on the stability of the income tax laws to hold the employee to the firm." 52 The action of the stock market, which may imduce the optionee to stay in the employ of the corporation, also cannot be the binding force necessary under an option plan. ${ }^{53}$

Facts surronnding a stock option plan often have been found to disclose the necessary "insurance." Evidence that but for the grant of the option, an employee would have terminated his services ${ }^{54}$ or that the option could not be exercised unless the optionee was in the employ of the firm ${ }^{55}$ has been held to be sufficient binding force for the corporation to receive the contemplated benefits. A covenant by the optionee to divest himself of outside business holdings also has been held to bind him to the company. ${ }^{58}$

How long the optionee must be "tied" to the firm to satisfy this requirement of "insurance" seems to be an open question. "Tying" periods of one year have consistently been upheld..$^{57}$

\section{Pre-emptive Rights}

As a rule at common law pre-emptive rights did not apply to stock issued in consideration of services. ${ }^{58}$ Today under modern statutes, however, difficulties involving pre-emptive rights may arise upon the issuance of stock under an option plan.$^{59}$ This has not been a formidable obstacle to

40 Holthusen v. Edward G. Budd Mfg. Co., 52 F.Supp. 125 (E.D.Pa. 1943); Kerbs v. California Eastern Airways, Inc., supra note 22 at 657 (by implication) ; Kaufman v. Shoenberg, supra note 25 at 792 ; cf. Holthusen v. Edward G. Budd. Mfg. Co., 53 F. Supp. 488 (E.D. Pa. 1943).

to See Kaufman v. Shoenberg, supra note 25 at 792 ; Wyles v. Campbell, supra note 33.

51 See Holthusen v. Edward G. Budd Mfg. Co., 52 F.Supp. 125, 130 (E.D. Pa. 1943).

E2 Kerbs v. California Eastern Airways, Inc., supra note 22 at 657.

03 Holthusen v. Edward G. Budd Mfg. Co., supra note 51 at 130.

04 Wise v. Universal Corp., 93 F. Supp. 393 (D.C. Del. 1950); Wyles v. Campbell, supra note 33 ; Sandler v. Schenley Ind. Inc., 79 A.2d 606 (Del. Ch. 1951).

55 Clamitz v. Thatcher Mfg. Co., stupra note 28. McQuillen v. National Cash Register Co., supra note 28; Eliasburg v. Standard Oil Co., supra note 23.

50 Sandler v. Schenley Ind. Inc., supra note 54.

57 Eliasberg v. Standard Oil Co., supra note 23. Compare the two Holthusen v. Edward G. Budd Mfg. Co. opinions, supra note 49.

5s BallaNtine, op. cit. supra note 24 at 490 (see discussion and cases cited).

69 Some statutes specifically provide that pre-emptive rights shall exist if not abrogated by the articles. FLA. Stat. \$ 612.20 (1949); N. J. Rev. Stat. \$ 14: 8-17 (1937) ; Irc. Rev. Stats. c. $32, \$ \$ 157.47(\mathrm{k})$ and $157.52(\mathrm{o})(1949)$. Others tacitly assume such rule and provide that they may be limited by articles. Dex. Rev. Code c. 65,813 (1935); MICH. Comp. Laws $\S 450.31$ (1948). Still others deny such rights unless the articles provide for them. CAI. Corp. ConE $\$ 1106$; PA. Stats. tit. 15, § 2852-611 (1936). For a more complete list of citations see BAIIANtine, Lattin and Jennings, Cases and Materials on Corporations n.1, 667 (1953). 
overcome. Often statutes expressly provide for amending away this right where stock option plans are concerned ${ }^{60}$ Delaware found the power in the corporation to amend away the pre-emptive right from the general amending power given by statute. ${ }^{.1}$ New York on this precise point had ruled contra. ${ }^{62}$

Since the original grant of pre-emptive rights is within the control of the incorporators, and, because ordinarily this right when in the articles can be amended away by the requisite shareholder vote, the minority shareholder has little protection in this sphere. ${ }^{.3}$

\section{Ratification by Shareholders}

The mere ratification of a plan cannot be accepted as conclusive of its validity. ${ }^{64}$ Unless it is unanimous, ratification cannot legitimatize a "gift" or waste of corporate assets. ${ }^{85}$ However, the burden of proof which the attacking minority shareholder must overcome when ratification has been obtained has been demonstrated to be virtually insurmountable. ${ }^{60}$

For a valid ratification, the general rule is that full and fair disclosure of all material facts to the shareholders is necessary. ${ }^{67}$ However, this rule may be quite misleading, since much infornation that one might consider "material" has been validly omitted from proxy requests and other literature sent to the shareholders concerning a stock option plan. For example, courts have upheld the ratification even though these facts were not disclosed: (1948).

60 N.Y. Stock CoRp. Law $\$ 35$; Cal. Corp. Code $\S 3634 ;$ Mich. Comp. Laws $\$ 450.31$

01 Gottlieb v. Heyden Chemical Corp., stupra note 22. Dex. REv. CODE c. $65 \S 26$ (1935), repealed and reenacted DEL. REv. CoDE tit. 8, c. 1, \& 242 (1953).

62 Albrecht, Maguire \& Co. v. General Plastic, Inc., 256 App. Div. 134, 9 N.Y.S.2d 415 (4th Dept. 1939), aff'd mem., 280 N.Y. 840, 21 N.E. 2d 887 (1939). Today, however, N.Y. STOCK CORP. LAW \& 35 expressly authorizes elimination of pre-emptive rights by direct charter amendment.

63 PA. STat. tit. 15, \& 2852-612 (1936) (two-tlirds vote of those entitled to pre-emptive right required); $c f$. CAL. CORP. CODE $\$ 1108$ (shares issued under stock purchase plan require two-thirds vote of those entitled to pre-emptive right). For general discussion of elimination by charter amendment of pre-emptive rights see 100 U. OF PA. L. REv. 902 (1952); Note, 3 UTAF L. REv. 140 (1952).

64 Kerbs v. California Eastern Airways, Inc., supra note 22 ; Keenan v. Eshleman, 23 Del. Ch. 234, 2 A.2d 904 (1938); Blish v. Thompson Automatic Arms Corp., 30 Del. Ch. 538, 64 A.2d 581 (1948); Eliasberg v. Standard Oil Co., supra note 23 ; BaIIAntnNe, op. cit. supra note 24, §60. Cf. Remillard Brick Co. v. Remillard-Dandini Corp., 109 Cal. App. 2d 405, 241 P.2d 66 (1952) ; S. Solomont and Sons Trust v. New England Th. Op. Corp., 326 Mass. 99, 93 N.E.2d 241 (1950).

65 Rodgers v. Hill, supra note 27 (" . . the majority stockholders have no power to give away corporate property against the protest of the minority"); Gottlieb v. Heyden Chemical Corp., supra note 22 .

60 ". . . the court will look into the transaction only far enough to see whether the terms are so unequal as to amount to waste, or whether, on the other hand, the question is such a close one as to call for the exercise of what is commonly called 'busimess judgment'. In the former case the court will reverse the decision of the stockholders; in the latter it wil not." Ehasberg v. Standard Oil Co., supra note 23 at 868.

67 See BaILANTINE, op. cit. supra note 24,871 . 
(1) That interested directors' stock was necessary to carry the vote ${ }^{\text {bs }}$ (amount of stock directors owned misrepresented to an extent);

(2) The amount of other compensation of interested directors; ${ }^{69}$

(3) Names of interested officers and directors; ${ }^{70}$

(4) That no independent quorum of directors voted for the plan; ${ }^{71}$

(5) The tax disadvantages to corporation of the stock option plan; ${ }^{72}$

(6) That beneficiaries under a stock option plan were already beneficiaries under a profit-sharing plan; ${ }^{73}$

(7) The terms upon which the options were to be issued and exercised. ${ }^{74}$

Courts are more apt to find full disclosure when the literature or proxy has been approved by the Securities Exchange Commission, ${ }^{75}$ even though this does not imply truthfulness or accuracy of the proxy. ${ }^{76}$ The SEC might well reëxamine the extent of disclosure now required in the proxy statement in view of this fact. ${ }^{76 a}$

Ratification by the shareholders of a plan submitted to them authorize the directors to take action only within the framework of the plan so ratified. ${ }^{7 \pi}$ Ratification of a present plan does not authorize the issuance of future options not covered by the immediate plan. ${ }^{78}$ The execution of a plan must be accomplished within the legal standards set down and approved by the shareholders.

The right of the directors to amend or control the operation of a stock option plan does not invalidate the plan or the ratification by the shareholders. But the directors or a subcommittee must still act within the limits of the plan as ratified. ${ }^{\text {9 }}$

\section{CONCLUSTON}

Section 130 A must be complied with to secure tax advantages. Basic corporation law establishes the requirements for validity of the stock op-

08 Kerbs v. California Eastern Airways, Inc., 94 A.2d 217, 218 (Ch. Del. 1953) (appeal from decision on profit sharing plan segment of original Kerbs case, supra note 22).

69 Kaufman v. Shoenberg, supra note 25 at 790.

70 Eliasberg v. Standard Oil Co., supra note 23 at 872.

71 Kerbs v. California Eastern Airways, Inc., supra note 68.

72 Kaufman v. Shoenberg, supra note 25 at 795 ; Eliasberg v. Standard Oil Co., supra note 23 at 868 .

73 Kaufman v. Shoenberg, supra note 25 at 790.

74 Ehiasberg v. Standard Oil Co., supra note 23 at 872.

T5 See Eliasberg v. Standard Oil Co., supra note 23 at 869. Proposed SEC Reg. E (Release No. 3458-X) would have the effect of permitting a postponement of time for filing an SEC registration statement covering issuance of stock under $\S 130 \mathrm{~A}$ of the INT. REV. CODE in certain instances.

76 Securities Exchange Act of 1934, § 26, 15 U.S.C. $\$ 78 z$ (1946).

76a See SEC v. Ralston Purina Co., 346 U.S. 119 (1953), reversing 200 F.2d 85 (8th Cir. 1952) (stock offerings to employees are public offerings under $\S 4(1)$ of the Securities Act of 1933 [15 U.S.C. $\S 77$ d], hence the registration requirements of $\S 5$ [15 U.S.C. $\S 77$ (e) (a) (1)] apply).

77 Eliasberg v. Standard Oil Co., supra note 23 at 873 ; Gottheb v. Heyden Chemical Corp., supra note 22 at 665,666 .

78 Ibid.

70 Kaufman v. Slooenberg, supra note 25 at 795 . However, local law unust allow this delegation of authority. 
tion plan itself. By combiming the requirements of $130 \mathrm{~A}$ and corporation law a seemingly injunction-proof plan is easily assembled, ${ }^{80}$ which will secure for the recipients entrepreneur benefits. ${ }^{81}$ Necessary ingredients would seem to be:

(1) That the option meet the requirements of Section 130A.

(2) That the aggregate compensation to optionees including any value attributable to the option be reasonable.

(3) That the stated objectives of the plan include the retention of existing employees' services, or inducement to others to enter the company's employ.

(4) That retention or acquistion of such services be stipulated as the consideration for the options.

(5) That optionees be required to perform services for a material period of time before they are granted an option and have the privilege of exercising it. An employment contract easily fulfills this requirement.

(6) That ratification by majority of shareholders of the objectives and content of the plan be obtained. All material facts should be disclosed to the shareholders. Listed companies, as well as unlisted companies using the mails or other interstate facilities, must submit proxy statements to the SEC. ${ }^{81 a}$

(7) That a time limit be set beyond which an option cannot be granted or exercised.

(8) That any pre-emptive rights of the shareholder be complied with, waivers obtained, or the barrier removed by amendment.

(9) That all applicable local law be followed.

Minority shareholders today will have an extremely difficult time invalidating a stock option plan. Management and the directors have the advantage of the business judgment rule. They also prepare the proxy statement, and may apparently omit seemingly material facts when soliciting ratification. An option recipient is also easily "tied" to the corporation so that the burden placed on the objector when attacking an option is virtually insurmountable. However, the minority shareholder still has an important task cut out for him. All of the recent cases have emphasized with surprising clarity that courts will scrutinize a stock option plan to determine if the directors have acted in good faith and if the plan is fair and reasonable to the corporation. These questions will not be decided on demurrer or

80 A number of problems are raised where a stock option plan is declared invalid. Can the recipients of stock under a void plan be forced to disgorge the difference between the market price and the purchase price? Are the directors liable for waste? Are the directors under a duty to recover any detriment to the corporation because of the void plan; and if they fail to do so are the directors themselves hable? See Rogers v. Hill, supra note 27; Fogelson v. American Woolen Co., Inc., 170 F.2d 660 (2d Cir. 1948); BaLlantine, supra note 24, §77; WASHINGTON AND RothSCHID, supra note 1 at $401,415$.

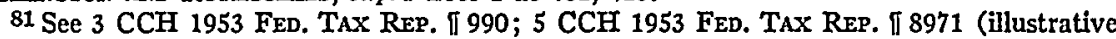
cases).

81a Securities Exchange Act of $1934 \S 14,15$ U.S.C. $\$ 77 n$ (1946). 
summary judgment, ${ }^{82}$ and the door is always open to convince a court that a plan is deficient. The threat of a minority shareholder suit in itself will force management and directors to treat shareholders more fairly than they otherwise might.

The mmority shareholder has in the past contributed much to secure a fair stock option plan. In the future, he will no doubt continue these efforts, merely weighing his objectives more carefully $\mathrm{m}$ light of present trends in the law. The barriers for the corporation will not, however, prove insurmountable in achieving the ultimate goal - a favorable stock option plan. ${ }^{83}$

Eugene Garfinkle

82 It is not enougb that the directors honestly believe that the plan is fair and reasonable, nor is it enough that the plan states that it is fair and reasonable. Gottlieb v. Heyden Chemical Corp., supra note 22 at 664 .

83 For defects and criticism of stock option plans see SurRey aND WARREN, op. cit. supra note 4 at 603 ; Mann, Deferred Compensation and Stock Option Plans Must be Legal, but Are They Ethical?, 93 J. Accountancy 324 (1952); Lyon, supra note 6; 36 A.B.A.J. 999, 1059 (1950). 